\title{
UJI EFEKTIVITAS PUPUK ORGANONITROFOS DAN KOMBINASINYA DENGAN PUPUK KIMIA TERHADAP PERTUMBUHAN, SERAPAN HARA DAN PRODUKSI TANAMAN CABAI MERAH KERITING (Capsicum annuum L.) PADA TANAH ULTISOL, GEDONG MENENG
}

\author{
Sopiyani, J. Lumbanraja, Dermiyati \& M. A. Syamsul Arif \\ Jurusan Agroteknologi, Fakultas Pertanian Universitas Lampung \\ Jl. Prof. Dr. Soemantri Brodjonegoro no. 1 Bandar Lampung 35145
}

\begin{abstract}
ABSTRAK
Pupuk Organonitrofos merupakan jenis pupuk organik yang berasal dari proses pengomposan kotoran sapi segar dan batuan fosfat yang ditambahkan mikroba pelarut fosfat dan mikroba penambat nitrogen. Penelitian ini bertujuan untuk mengetahui dosis pupuk Organonitrofos dan kombinasinya dengan pupuk kimia yang menghasilkan pertumbuhan, produksi dan serapan hara terbaik pada tanaman cabai merah keriting, dan menetapkan efektivitas pupuk Organonitrofos dan kombinasinya dengan pupuk kimia secara agronomi (RAE) dan ekonomi pada tanaman cabai merah keriting. Penelitian ini dilakukan di Laboratorium Lapang Terpadu Fakultas Pertanian Universitas Lampung Gedong Meneng pada titik koordinat 5'22' 10" LS dan 105 14'38" BT dengan ketinggian $146 \mathrm{~m}$ di atas permukaan laut dan Laboratorium Ilmu Tanah Fakultas Pertanian Universitas Lampung. Penelitian lapang dilaksanakan dari bulan Oktober 2012 sampai Maret 2013. Penelitian ini terdiri dari 6 perlakuan dengan 3 ulangan disusun dalam Rancangan Acak kelompok (RAK). Perlakuan yang digunakan yaitu: A (Kontrol), B (300 kg urea

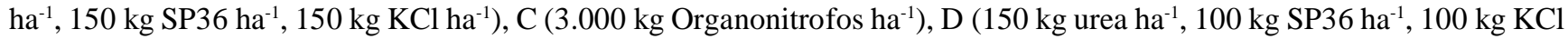
$\mathrm{ha}^{-1}, 500 \mathrm{~kg}$ Organonitrofos ha $\left.{ }^{-1}\right), \mathrm{E}\left(100 \mathrm{~kg}\right.$ urea ha- ${ }^{-1}, 50 \mathrm{~kg} \mathrm{SP} 6 \mathrm{ha}^{-1}, 50 \mathrm{~kg} \mathrm{KCl} \mathrm{ha}^{-1}, 1.000 \mathrm{~kg}^{-1}$ Organonitrofos ha-1), F $(100 \mathrm{~kg}$ urea ha- ${ }^{-1}, 50 \mathrm{~kg} \mathrm{SP}_{6} 6 \mathrm{ha}^{-1}, 50 \mathrm{~kg} \mathrm{KCl} \mathrm{ha}{ }^{-1}, 2.000 \mathrm{~kg}$ Organonitrofos ha- ${ }^{-1}$. Data dianalisis dengan analisis ragam dan perbedaan nilai tengah perlakuan dengan uji Beda Nyata Terkecil (BNT) pada taraf nyata 5\%. Hasil penelitian menunjukkan: Pemberian pupuk Organonitrofos dan kombinasinya dengan pupuk kimia tidak berpengaruh terhadap pertumbuhan, bobot basah dan kering berangkasan, serapan NPK tanaman, dan NPK tanaman + buah cabai merah keriting. Perlakuan E (100 kg urea ha-1 ${ }^{-1}, 50$ kg SP36 ha- ${ }^{-1}, 50 \mathrm{~kg} \mathrm{KCl} \mathrm{ha}^{-1}, 1.000 \mathrm{~kg}$ Organonitrofos ha $\left.{ }^{-1}\right)$ dan F $\left(100 \mathrm{~kg}\right.$ urea ha- ${ }^{-1}, 50 \mathrm{~kg} \mathrm{SP}_{6} 6 \mathrm{ha}^{-1}, 50 \mathrm{~kg} \mathrm{KCl} \mathrm{ha}^{-1}, 2.000 \mathrm{~kg}$ Organonitrofos $\mathrm{ha}^{-1}$ ) berpengaruh nyata meningkatkan bobot segar, bobot kering buah dan serapan NPK buah cabai merah keriting. Tidak terdapat korelasi antara serapan NPK dengan tinggi tanaman. Terdapat korelasi antara serapan NPK dengan bobot segar, bobot kering buah dan bobot basah berangkasan cabai merah keriting. Perlakuan E efektif dalam meningkatkan produksi buah cabai merah keriting secara agronomis (RAE) dan ekonomis.
\end{abstract}

Kata Kunci: cabai merah keriting, kombinasi pupuk, Organonitrofos.

\section{PENDAHULUAN}

Cabai merah keriting (Capsicum annum L.) merupakan salah satu komoditas sayuran yang mempunyai nilai ekonomi tinggi dan ditanam secara meluas sehingga produksinya tersebar cukup luas di Indonesia (Nursanti, 2008). Kebutuhan akan cabai merah keriting tidak pernah surut cenderung terus meningkat, namun pada tahun 2012 mengalami penurunan menjadi 7,13 t ha-1 (BPS, 2012). Penurunan produksi diduga karena pemakaian pupuk kimia secara terus menerus sehingga mempengaruhi sifat fisik, kimia dan biologi tanah serta berdampak negatif terhadap lingkungan (Yusnaini dkk., 2004). Sehingga diperlukan upaya untuk memlihara kesuburan tanah dengan penambahan bahan organik. Pupuk Organonitrofos merupakan salah satu pupuk organik yang berasal dari proses pengomposan campuran kotoran sapi segar dan batuan fosfat alam (Nugroho dkk., 2012). Keunggulan pupuk organik ini memiliki kandungan $\mathrm{N}$ dan $\mathrm{P}$ yang lebih tinggi dari pupuk organik lainnya karena ditambahkan mikroba penambat $\mathrm{N}$ ( $\mathrm{N}$-fixer) dan mikroba pelarut fosfat (P-solubilizer) (Nugroho dkk., 2013).

Hasil penelitian Christine (2013) menunjukan bahwa kombinasi pupuk Organonitrofos dengan pupuk

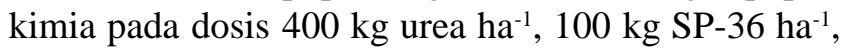
$100 \mathrm{~kg} \mathrm{KCl} \mathrm{ha}^{-1}, 2.000 \mathrm{~kg}$ Organonitrofos ha- ${ }^{-1}$ dan pupuk 
Organonitrofos tunggal dengan dosis $5.000 \mathrm{~kg} \mathrm{ha}^{-1}$ Organonitrofos efektif dalam meningkatkan pertumbuhan dan produksi tanaman cabai rawit khatur sebesar $32-120 \%$. Sehingga kombinasi pupuk Organonitrofos dengan pupuk kimia ini diharapkan dapat meningkatkan produksi cabai. Tujuan dari penelitian ini adalah untuk mengetahui dosis pupuk Organonitrofos dan kombinasinya dengan pupuk kimia yang menghasilkan pertumbuhan, produksi dan serapan hara terbaik pada tanaman cabai merah keriting, dan menetapkan efektifitas pupuk Organonitrofos dan kombinasinya dengan pupuk kimia secara agronomi (RAE) dan ekonomi pada tanaman cabai merah keriting.

\section{BAHAN DAN METODE}

Penelitian ini dilakukan di Laboratorium Lapang Terpadu Fakultas Pertanian Universitas Lampung Gedong Meneng pada titik koordinat $5^{\circ} 22^{\prime} 10^{\prime \prime} \mathrm{LS}$ dan $105^{\circ} 14$ ' 38" BT dengan ketinggian $146 \mathrm{~m}$ di atas permukaan laut dan Laboratorium Ilmu Tanah Fakultas Pertanian Universitas Lampung dari bulan Oktober 2012 sampai Maret 2013. Penelitian ini terdiri dari 6 perlakuan dengan 3 ulangan disusun dalam Rancangan Acak Kelompok (RAK). Perlakuan yang diaplikasikan yaitu: $\mathrm{A}=$ kontrol, $\mathrm{B}=300 \mathrm{~kg}$ urea ha-1, $150 \mathrm{~kg} \mathrm{SP} 36 \mathrm{ha}^{-1}$, $150 \mathrm{~kg} \mathrm{KCl} \mathrm{ha}^{-1}, \mathrm{C}=3.000 \mathrm{~kg}$ Organonitrofos ha- ${ }^{-1}, \mathrm{D}=$ $150 \mathrm{~kg}$ urea ha- ${ }^{-1}, 100 \mathrm{~kg} \mathrm{SP} 36 \mathrm{ha}^{-1}, 100 \mathrm{~kg} \mathrm{KCl} \mathrm{ha}{ }^{-1}$, $500 \mathrm{~kg}$ Organonitrofos ha ${ }^{-1}, \mathrm{E}=100 \mathrm{~kg}$ urea ha $^{-1}, 50 \mathrm{~kg}$ SP36 ha ${ }^{-1}, 50 \mathrm{~kg} \mathrm{KCl} \mathrm{ha}^{-1}, 1.000 \mathrm{~kg}$ Organonitrofos ha${ }^{1}, \mathrm{~F}=100 \mathrm{~kg}$ urea ha ${ }^{-1}, 50 \mathrm{~kg} \mathrm{SP} 36 \mathrm{ha}^{-1}, 50 \mathrm{~kg} \mathrm{KCl} \mathrm{ha-}$ ${ }^{1}, 2.000 \mathrm{~kg}$ Organonitrofos ha-1). Tanah yang menjadi media tanam dibagi 18 petak dengan berkuran $3 \times 3 \mathrm{~m}$ dengan jarak antar petak $70 \mathrm{~cm}$. Bibit cabai yang telah berumur 30 hari dipindahkan ke lahan dan ditanam dengan jarak tanam $50 \times 50 \mathrm{~cm}$. Aplikasi pupuk Organonitrofos dan pupuk kimia berupa pupuk Urea, SP-36 dan $\mathrm{KCl}$ diberikan saat tanam. Pemberian pupuk urea dilakukan sebanyak dua kali yaitu setengah pupuk urea dilakukan setelah tanah siap ditanam bersamaan dengan pupuk organonitrofos, SP-36 dan $\mathrm{KCl}$. Aplikasi kedua setengah dosis pupuk urea dilakukan saat bunga muncul. Penyiraman dilakukan setiap hari sebanyak dua kali yaitu pagi dan sore hari. Pemberian mulsa tersebut disebar merata pada masing-masing petak percobaan. Ajir digunakan untuk menopang tanaman cabai agar tidah rebah. Penyiangan dilakukan dengan melihat keberadaan gulma yang tumbuh dengan menggunakan koret. Pengendaliam hama dan penyakit dilakukan secara mekanik dengan mengumpulkam semua buah cabai yang rontok, pembersihan semua gulma dan sisa tanaman inang kutu daun yang ada di sekitar areal pertanaman cabai merah keriting. Dalam penelitian ini pemanenan tanaman cabai merah keriting dilakukan sebanyak 10 kali panen, cabai dipanen sekitar 70 Hari Setelah Tanam (HST) atau warna buah sudah mulai merah. Variabel yang diamati pada penelitian ini meliputi tinggi tanaman, jumlah cabang, bobot berangkasan, bobot segar buah dan analisis tanaman. Data pendukung yaitu analisis tanah, uji RAE pupuk Organonitrofos, dan uji ekonomis pupuk. Data dikelompokkan berdasarkan ulangan dan keserentakan analisis di laboratorium. Homogenitas ragam diuji dengan uji Bartlet, aditivitas data diuji dengan uji Tukey. Data dianalisis dengan sidik ragam, perbedaan nilai tengah perlakuan diuji denga uji Beda Nyata Terkecil (BNT) pada taraf $5 \%$.

\section{HASIL DAN PEMBAHASAN}

Sifat Kimia Tanah dan Pupuk Organonitrofos. Analisis tanah awal dilakukan sebelum perlakuan yaitu saat pengolahan tanah dan setelah perlakuan. Dari hasil analisis (Tabel 1) pemberian pupuk Organonitrofos maupun kombinasinya dengan pupuk kimia menghasilkan adanya perbaikan sifat kimia tanah disajikan pada (Tabel

Tabel 1. Hasil Analisis Tanah Awal dan Pupuk Organonitrofos.

\begin{tabular}{lccc}
\hline \multicolumn{1}{c}{ Jenis Analisis } & Tanah & Kriteria* & Organonitrofos \\
\hline $\mathrm{pH}\left(\mathrm{H}_{2} \mathrm{O}\right)$ & 5,77 & Agak masam & 7,28 \\
C-Organik $(\%)$ & 1,47 & Rendah & 2,38 \\
N-Total $(\%)$ & 0,27 & Sedang & 0,35 \\
P-Total $(\%)$ & 0,033 & Rendah & 0,31 \\
K-Total $(\%)$ & 0,022 & Rendah & 0,91 \\
P-Tersedia $\left(\mathrm{ppm}^{-1}\right.$ & 7,28 & Sedang & \\
K-dd $\left(\right.$ me $\left.100 \mathrm{~g}^{-1}\right)$ & 0,52 & Sedang & \\
\hline
\end{tabular}

*) Sumber kriteria: Balai Penelitian Tanah, 2005. 
2). Berdasarkan hasil analisis tanah menunjukkan bahwa pemberian pupuk Organonitrofos maupun kombinasinya dengan pupuk kimia pada tanaman cabai dapat memperbaiki $\mathrm{pH}$ tanah dari 5.77 - 6.13. kandungan Corganik meningkatkan dari 1,47\% menjadi 2,21\%, peningkatan kandungan C-organik tersebut disebabkan oleh terjadinya dekompisisi bahan organik dalam tanah. Hasil penelitian Elisabeth, dkk., (2012) pada tanaman bawang merah menunjukkan peningkatan dari 1,59 manjadi $1,61 \%-1,93 \%$. Kandungan $\mathrm{N}$-total meningkat dari $0,27 \%$ menjadi $0.66 \%$ tergolong tinggi. Kadar Ptersedia diperoleh hasil yang paling tinggi yaitu sekitar 7,78-11,0 ppm. Meningkatnya kadar P-tersedia dalam tanah disebabkan oleh pemberian pupuk $\mathrm{P}$ dengan dosis yang tinggi sebanyak $250 \mathrm{~kg} \mathrm{ha}^{-1}$, sedangkan kadar $\mathrm{P}$ yang diserap oleh tanaman sedikit.
Pengaruh Pemupukuan Organonitrofos dan Kombinasinya dengan Pupuk Kimia terhadap Pertumbuhan dan Produksi Tanaman Cabai Merah Keriting. Hasil penelitian menunjukkan bahwa semua perlakuan pemupukan tidak berpengaruh nyata terhadap tinggi dan jumlah cabang tanaman (Gambar 1). Hal ini diduga karena lahan yang digunakan dalam penelitian ini merupakan lahan yang baru di buka dari semak belukar. Lahan yang baru dibuka pada masa fase bera pendek merupakan fase pemulihan kesuburan sebab proses penumpukan serasah daun yang terjadi secara terus menerus menutupi tanah akan menjadi sumber unsur hara bagi tanah (Mulyoutami, dkk., 2010).

Berdasarkan hasil uji BNT (Tabel 3) menunjukkan bahwa perlakuan E (100 kg urea ha-1, 50 $\mathrm{kg} \mathrm{SP} 36 \mathrm{ha}^{-1}, 50 \mathrm{~kg} \mathrm{KCl} \mathrm{ha}{ }^{-1}, 1.000 \mathrm{~kg}$ Organonitrofos

Tabel 2. Hasil analisis tanah setelah aplikasi pupuk Organonitrofos dan kombinasinya dengan pupuk kimia.

\begin{tabular}{cccccc}
\hline \multirow{2}{*}{ Perlakuan } & \multicolumn{5}{c}{ Jenis Analisis } \\
\cline { 2 - 6 } & N- Total (\%) & P-Tersedia (ppm) & K-dd (me $\left.100 \mathrm{~g}^{-1}\right)$ & C-Organik (\%) & $\mathrm{pH}\left(\mathrm{H}_{2} \mathrm{O}\right)$ \\
\hline A & $0,11(\mathrm{R})$ & $3,91(\mathrm{R})$ & $0,50(\mathrm{~S})$ & $1,39(\mathrm{R})$ & 6,13 \\
B & $0,66(\mathrm{~T})$ & $5,68(\mathrm{R})$ & $0,55(\mathrm{~S})$ & $1,86(\mathrm{R})$ & 6,15 \\
C & $0,25(\mathrm{~S})$ & $5,25(\mathrm{R})$ & $0,56(\mathrm{~S})$ & $2,21(\mathrm{~S})$ & 6,39 \\
D & $0,22(\mathrm{~S})$ & $7,78(\mathrm{~S})$ & $0,66(\mathrm{~T})$ & $2,29(\mathrm{~S})$ & 6,49 \\
E & $0,13(\mathrm{R})$ & $7,78(\mathrm{~S})$ & $0,68(\mathrm{~T})$ & $2,07(\mathrm{~S})$ & 6,37 \\
F & $0,16(\mathrm{R})$ & $11,6(\mathrm{~T})$ & $0,57(\mathrm{~S})$ & $2,05(\mathrm{~S})$ & 6,38 \\
\hline
\end{tabular}

Keterangan : A = tanpa pemupukan, B $=300 \mathrm{~kg}$ urea ha ${ }^{-1}, 150 \mathrm{~kg} \mathrm{SP} 6 \mathrm{ha}^{-1}, 150 \mathrm{~kg} \mathrm{KCl} \mathrm{ha}^{-1}, \mathrm{C}=3000 \mathrm{~kg}$ Organonitrofos ha- $\mathrm{ha}^{-1}, \mathrm{D}=150 \mathrm{~kg}_{\text {urea ha }}{ }^{-1}, 100 \mathrm{~kg} \mathrm{SP} 6 \mathrm{ha}^{-1}, 100 \mathrm{~kg} \mathrm{KCl} \mathrm{ha}^{-1}, 500 \mathrm{~kg}$ Organonitrofos

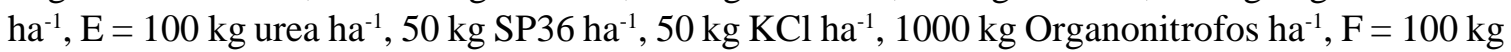

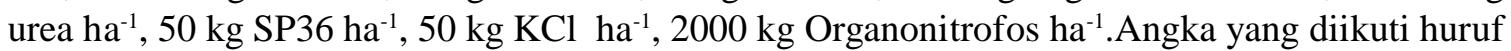
menyatakan $\mathrm{T}=$ tinggi, $\mathrm{S}=$ sedang, $\mathrm{R}=$ rendah, $\mathrm{SR}=$ sangat rendah (Balai Penelitian Tanah, 2005).

Tabel 3. Pengaruh pemupukan Organonitrofos dan kombinasinya dengan pupuk kimia terhadap produksi tanaman cabai merah keriting.

\begin{tabular}{ccccc}
\hline Perlakuan $\left(\mathrm{kg} \mathrm{ha}^{-1}\right)$ & \multicolumn{3}{c}{ Bobot segar buah $\left(\mathrm{t} \mathrm{ha}^{-1}\right)$} & Bobot kering buah $\left(\mathrm{t} \mathrm{ha}^{-1}\right)$ \\
Urea - SP36 - KCl - Organonitrofos & 0,98 & $\mathrm{a}$ & 0,20 & $\mathrm{ab}$ \\
\hline A $(0-0-0-0)$ & 1,05 & $\mathrm{a}$ & 0,21 & $\mathrm{ab}$ \\
B $(300-150-150-0)$ & 0,96 & $\mathrm{a}$ & 0,19 & $\mathrm{a}$ \\
C $(0-0-0-3000)$ & 0,95 & $\mathrm{a}$ & 0,18 & $\mathrm{a}$ \\
D $(150-100-100-500)$ & 1,33 & $\mathrm{~b}$ & 0,24 & $\mathrm{~b}$ \\
E $(100-50-50-1000)$ & 1,12 & $\mathrm{ab}$ & 0,23 & $\mathrm{~b}$ \\
F $(100-50-50-2000)$ & 0,21 & & 0,038 \\
\hline BNT 5\% & &
\end{tabular}

Keterangan : Angka yang diikuti huruf yang sama pada kolom yang sama tidak berbeda nyata pada uji BNT dengan taraf 5\%. 

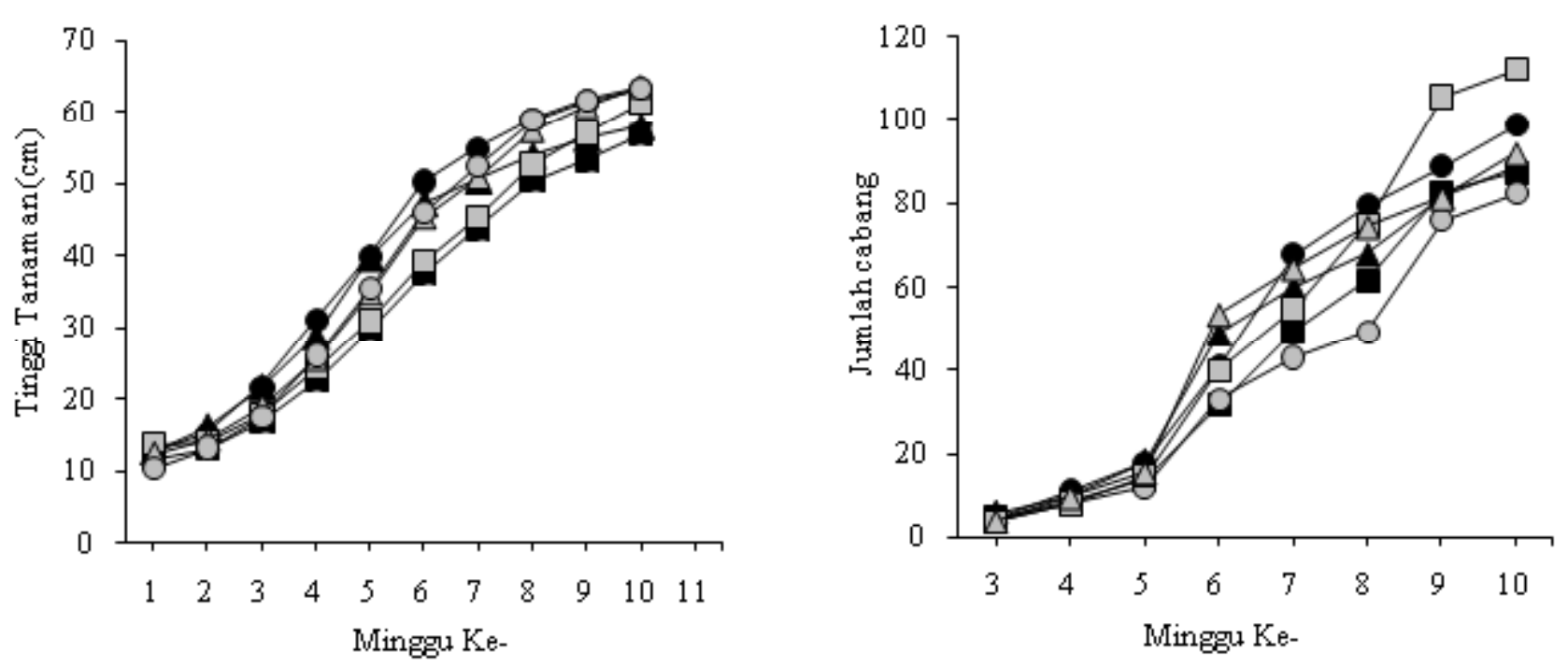

Gambar 1. Pengaruh pemberian pupuk Organonitrofos dan kombinasinya dengan pupuk kimia terhadap (a) tinggi tanaman (b) jumlah cabang pada cabai merah keriting. A $(-\bullet)=$ tanpa pemupukan, B $(-\mathbf{-})=300$ $\mathrm{kg}$ urea ha ${ }^{-1}, 150 \mathrm{~kg} \mathrm{SP} 36 \mathrm{ha}^{-1}, 150 \mathrm{~kg} \mathrm{KCl} \mathrm{ha}^{-1}, \mathrm{C}(-\mathbf{\star})=3.000 \mathrm{~kg}$ Organonitrofos ha ${ }^{-1}, \mathrm{D}(-\square-)=$ $150 \mathrm{~kg}$ urea ha-1, $100 \mathrm{~kg} \mathrm{SP} 36 \mathrm{ha}^{-1}, 100 \mathrm{~kg} \mathrm{KCl} \mathrm{ha}^{-1}, 500 \mathrm{~kg}^{-}$Organonitrofos ha-1, E $(-\triangleleft)=100 \mathrm{~kg}$ urea ha ${ }^{-1}, 50 \mathrm{~kg} \mathrm{SP} 6 \mathrm{ha}^{-1}, 50 \mathrm{~kg} \mathrm{KCl} \mathrm{ha}^{-1}, 1.000 \mathrm{~kg}$ Organonitrofos ha $^{-1}, \mathrm{~F}(-\circ)=100 \mathrm{~kg}^{-}$urea ha $^{-1}$, $50 \mathrm{~kg} \mathrm{SP} 36 \mathrm{ha}^{-1}, 50 \mathrm{~kg} \mathrm{KCl} \mathrm{ha}{ }^{-1}, 2.000 \mathrm{~kg}$ Organonitrofos ha $\mathrm{ha}^{-1}$.

$\left.\mathrm{ha}^{-1}\right)$ dan perlakuan $\mathrm{F}\left(100 \mathrm{~kg}\right.$ urea $\mathrm{ha}^{-1}, 50 \mathrm{~kg} \mathrm{SP} 36$ $\mathrm{ha}^{-1}, 50 \mathrm{~kg} \mathrm{KCl} \mathrm{ha}{ }^{-1}, 2.000 \mathrm{~kg}$ Organonitrofos ha-1) berpengaruh nyata meningkatkan produksi segar buah dan kering buah cabai merah keriting. Tingginya hasil produksi pada perlakuan E diduga karena sifat tanah pada perlakuan E menunjang pertumbuhan dan produksi cabai merah keriting. Perlakuan E (100 kg urea ha ${ }^{-1}$, $50 \mathrm{~kg}$ SP36 ha-1, $50 \mathrm{~kg} \mathrm{KCl} \mathrm{ha-1,} 1.000 \mathrm{~kg}$ Organonitrofos $\mathrm{ha}^{-1}$ ) memberikan bobot segar buah yang paling tinggi yaitu sebesar $1.33 \mathrm{tha}^{-1}$, dan bobot kering buah yaitu sebesar $0,24 \mathrm{tha}^{-1}$. Tingginya hasil produksi pada perlakuan E diduga karena sifat tanah pada perlakuan E menunjang pertumbuhan dan produksi cabai merah keriting. Penelitiaan Christine (2013) bahwa perlakuan E $\left(100 \mathrm{~kg}\right.$ urea ha ${ }^{-1}, 50 \mathrm{~kg} \mathrm{SP} 36 \mathrm{ha}^{-1}, 50 \mathrm{~kg}$ $\mathrm{KCl} \mathrm{ha}{ }^{-1}, 2.000 \mathrm{~kg}$ Organonitrofos ha ${ }^{-1}$ memberikan hasil lebih tinggi sebesar 1,48 $\mathrm{tha}^{-1}$ dibanding pelakuan kombinasi lainnya. Pupuk Organonitrofos dan kombinasinya dengan pupuk kimia terhadap bobot basah berangkasan dan bobot kering berangkasan menunjukkan bahwa perlakuan pada perlakuan $\mathrm{F}(100$ kg urea ha- ${ }^{-1}, 50 \mathrm{~kg} \mathrm{SP} 6 \mathrm{ha}^{-1}, 50 \mathrm{~kg} \mathrm{KCl} \mathrm{ha}{ }^{-1}, 2.000 \mathrm{~kg}$ Organonitrofos $\mathrm{ha}^{-1}$ ) diperoleh hasil sebesar 4,23 $\mathrm{t} \mathrm{ha}^{-1}$, sedangkan pada bobot kering sebesar 1,63 $\mathrm{t} \mathrm{ha}^{-1}$ (Tabel 4). Peningkatan bobot berangkasan diduga karena dipengaruhi oleh serapan hara $\mathrm{N}, \mathrm{P}$ dan $\mathrm{K}$ tanaman sehingga proses fotosintesis dapat berjalan sempurna yang berpengaruh terhadap kualitas dan kuantitas hasil akhir panen Setamidjaya (1986).

Pengaruh Pupuk Organonitrofos dan Kombinasinya dengan Pupuk Kimia terhadap Serapan Unsur Hara NPK pada Tanaman dan Buah Cabai Merah Keriting. Hasil Uji BNT (Tabel 5) menunjukkan bahwa pengaruh pupuk Organonitrofos dan kombinasinya dengan pupuk kimia tidak berpengaruh nyata terhadap serapan $\mathrm{N}$ pada tanaman dan $\mathrm{N}$ tanaman + buah. Pada buah berpengaruh nyata terhadap serapan N. Perlakuan F (100 kg urea ha ${ }^{-1}, 50 \mathrm{~kg} \mathrm{SP36} \mathrm{ha-1,} 50$ $\mathrm{kg} \mathrm{KCl} \mathrm{ha}{ }^{-1}, 2.000 \mathrm{~kg}$ Organonitrofos ha- ${ }^{-1}$ ) menghasilkan serapan $\mathrm{N}$ tertinggi pada buah sebesar $5,59 \mathrm{~kg} \mathrm{ha}^{-1}$. Syafruddin, dkk., (2007) menyatakan bahwa N diserap oleh tanaman terus menerus sampai mendekati matang.

Berdasarkan hasil Uji BNT menunjukkan pengaruh pupuk Organonitrofos dan kombinasinya dengan pupuk kimia tidak berpengaruh nyata terhadap serapan P pada tanaman dan P tanaman + buah, namun pada buah berpengaruh nyata terhadap serapan $\mathrm{P}$ (Tabel 6). Pada perlakuan E (100 kg urea ha ${ }^{-1}, 50 \mathrm{~kg} \mathrm{SP} 36 \mathrm{ha}^{-}$ ${ }^{1}, 50 \mathrm{~kg} \mathrm{KCl} \mathrm{ha}{ }^{-1}, 1.000 \mathrm{~kg}$ Organonitrofos ha ${ }^{-1}$ ) diperoleh serapan $\mathrm{P}$ tertinggi yaitu $1,53 \mathrm{~kg} \mathrm{ha}^{-1}$. Kadar $\mathrm{P}$ dalam tanah yang sudah jenuh mengakibatkan menurunnya tanggap tanaman terhadap pemupukan (Goenadi, 2006), sehingga pemupukan P perlu dilakukan untuk meningkatkan P tersedia dalam tanah. Hasil Uji 
Tabel 4. Pengaruh pemupukan Organonitrofos dan kombinasinya dengan pupuk kimia terhadap bobot berangkasan tanaman cabai merah keriting.

\begin{tabular}{ccccc}
\hline $\begin{array}{c}\text { Perlakuan }\left(\mathrm{kg} \mathrm{ha}^{-1}\right) \\
\text { Urea - SP36 - KCl - Orga nonitrofos }\end{array}$ & \multicolumn{2}{c}{ Bobot basah $\left(\mathrm{t} \mathrm{ha}^{-1}\right)$} & \multicolumn{2}{c}{ Bobot kering $\left(\mathrm{t} \mathrm{ha}^{-1}\right)$} \\
\hline A $(0-0-0-0)$ & 2,90 & $\mathrm{a}$ & 1,04 & $\mathrm{a}$ \\
B $(300-150-150-0)$ & 2,94 & $\mathrm{a}$ & 1,08 & $\mathrm{a}$ \\
C $(0-0-0-3000)$ & 2,92 & $\mathrm{a}$ & 1,06 & $\mathrm{a}$ \\
D $(150-100-100-500)$ & 3,54 & $\mathrm{a}$ & 1,33 & $\mathrm{a}$ \\
E $(100-50-50-1000)$ & 3,61 & $\mathrm{a}$ & 1,31 & $\mathrm{a}$ \\
F $(100-50-50-2000)$ & 4,23 & $\mathrm{a}$ & 1,63 & $\mathrm{a}$ \\
\hline BNT 5\% & 1,78 & & 0,62 & \\
\hline
\end{tabular}

Keterangan : Angka yang diikuti huruf yang sama pada kolom yang sama tidak berbeda nyata pada uji BNT dengan taraf $5 \%$.

Tabel 5. Pengaruh pemupukan Organonitrofos dan kombinasinya dengan pupuk kimia terhadap serapan unsur hara $\mathrm{N}$ cabai merah keriting $\left(\mathrm{kg} \mathrm{ha}^{-1}\right)$.

\begin{tabular}{ccccccc}
\hline Perlakuan $\left(\mathrm{kg} \mathrm{ha}^{-1}\right)$ & \multicolumn{5}{c}{ Serapan hara } \\
\cline { 2 - 7 } Urea - SP36 - KCl - Organonitrofos \\
\cline { 2 - 7 } & Tanaman $\left(\mathrm{kg} \mathrm{ha}^{-1}\right)$ & \multicolumn{3}{c}{ Buah $\left(\mathrm{kg} \mathrm{ha}^{-1}\right)$} & Tanaman + Buah $\left(\mathrm{kg} \mathrm{ha}^{-1}\right)$ \\
\hline A $(0-0-0-0)$ & 24,65 & $\mathrm{a}$ & 3,93 & $\mathrm{ab}$ & 28,57 & $\mathrm{a}$ \\
B $(300-150-150-0)$ & 30,52 & $\mathrm{a}$ & 5,20 & $\mathrm{~cd}$ & 35,72 & $\mathrm{a}$ \\
C $(0-0-0-3000)$ & 26,75 & $\mathrm{a}$ & 3,98 & $\mathrm{ab}$ & 30,74 & $\mathrm{a}$ \\
D $(150-100-100-500)$ & 31,32 & $\mathrm{a}$ & 3,45 & $\mathrm{a}$ & 34,77 & $\mathrm{a}$ \\
E $(100-50-50-1000)$ & 43,35 & $\mathrm{a}$ & 4,67 & $\mathrm{bc}$ & 48,02 & $\mathrm{a}$ \\
F $(100-50-50-2000)$ & 34,67 & $\mathrm{a}$ & 5,59 & $\mathrm{~d}$ & 40,26 & $\mathrm{a}$ \\
\hline BNT 5\% & 23,70 & & 0,86 & 24,28 & \\
\hline
\end{tabular}

Keterangan : Angka yang diikuti huruf yang sama pada kolom yang sama tidak berbeda nyata pada uji BNT dengan taraf $5 \%$.

Tabel 6. Pengaruh pemupukan Organonitrofos dan kombinasinya dengan pupuk kimia terhadap serapan unsur hara P cabai merah keriting $\left(\mathrm{kg} \mathrm{ha}^{-1}\right)$.

\begin{tabular}{ccccccc}
\hline Perlakuan $\left(\mathrm{kg} \mathrm{ha}^{-1}\right)$ & \multicolumn{7}{c}{ Serapan hara P } \\
\cline { 2 - 7 } Urea - SP36 - KCl - Organonitrofos & \multicolumn{7}{c}{ Tanaman $\left(\mathrm{kg} \mathrm{ha}^{-1}\right)$} & Buah $\left(\mathrm{kg} \mathrm{ha}^{-1}\right)$ & Tanaman + Buah $\left(\mathrm{kg} \mathrm{ha}^{-1}\right)$ \\
\hline A $(0-0-0-0)$ & 5,12 & $\mathrm{a}$ & 1,43 & $\mathrm{c}$ & 6,55 & $\mathrm{a}$ \\
B $(300-150-150-0)$ & 6,60 & $\mathrm{a}$ & 1,30 & $\mathrm{bc}$ & 7,90 & $\mathrm{a}$ \\
C $(0-0-0-3000)$ & 5,52 & $\mathrm{a}$ & 0,77 & $\mathrm{a}$ & 6,29 & $\mathrm{a}$ \\
D $(150-100-100-500)$ & 7,83 & $\mathrm{a}$ & 1,11 & $\mathrm{~b}$ & 8,94 & $\mathrm{a}$ \\
E $(100-50-50-1000)$ & 7,47 & $\mathrm{a}$ & 1,53 & $\mathrm{c}$ & 8,99 & $\mathrm{a}$ \\
F $(100-50-50-2000)$ & 9,65 & $\mathrm{a}$ & 1,48 & $\mathrm{c}$ & 11,13 & $\mathrm{a}$ \\
\hline BNT 5\% & 5,32 & \multicolumn{7}{c}{0,25} \\
\hline
\end{tabular}

Keterangan : Angka yang diikuti huruf yang sama pada kolom yang sama tidak berbeda nyata pada uji BNT dengan taraf $5 \%$.

BNT (Tabel 7) menunjukkan bahwa pengaruh pupuk Organonitrofos dan kombinasinya dengan pupuk kimia tidak berpengaruh nyata terhadap serapan $\mathrm{K}$ pada tanaman dan K tanaman + buah. Namun pada buah berpengaruh nyata terhadap serapan K. Dalam penelitian Septima (2013) menunjukkan dengan dosis kombinasi pupuk Organonitrofos dengan pupuk kimia dengan dosis $100 \mathrm{~kg}$ urea ha $^{-1}, 50 \mathrm{~kg} \mathrm{SP} 36 \mathrm{ha}^{-1}, 100 \mathrm{~kg}$ 
Tabel 7. Pengaruh pemupukan Organonitrofos dan kombinasinya dengan pupuk kimia terhadap serapan unsur hara $\mathrm{K}$ cabai merah keriting $\left(\mathrm{kg} \mathrm{ha}^{-1}\right)$.

\begin{tabular}{ccccccc}
\hline Perlakuan $\left(\mathrm{kg} \mathrm{ha}^{-1}\right)$ & \multicolumn{7}{c}{ Serapan hara K } \\
\cline { 2 - 7 } Urea - SP36 - KCl - Organonitrofos & \multicolumn{7}{c}{ Tanaman $\left(\mathrm{kg} \mathrm{ha}^{-1}\right)$} & \multicolumn{3}{c}{ Buah $\left(\mathrm{kg} \mathrm{ha}^{-1}\right)$} & Tanaman + Buah $\left(\mathrm{kg} \mathrm{ha}^{-1}\right)$ \\
\hline A $(0-0-0-0)$ & 19,32 & $\mathrm{a}$ & 2,96 & $\mathrm{ab}$ & 22,29 & $\mathrm{a}$ \\
B $(300-150-150-0)$ & 15,80 & $\mathrm{a}$ & 3,32 & $\mathrm{abc}$ & 19,12 & $\mathrm{a}$ \\
C $(0-0-0-3000)$ & 21,49 & $\mathrm{a}$ & 4,56 & $\mathrm{~d}$ & 26,05 & $\mathrm{a}$ \\
D $(150-100-100-500)$ & 21,37 & $\mathrm{a}$ & 2,67 & $\mathrm{a}$ & 24,02 & $\mathrm{a}$ \\
E $(100-50-50-1000)$ & 22,00 & $\mathrm{a}$ & 3,74 & $\mathrm{c}$ & 25,74 & $\mathrm{a}$ \\
F $(100-50-50-2000)$ & 24,20 & $\mathrm{a}$ & 3,50 & $\mathrm{bc}$ & 27,70 & $\mathrm{a}$ \\
\hline BNT 5\% & 8,67 & & 0,66 & & 8,89 &
\end{tabular}

Keterangan : Angka yang diikuti huruf yang sama pada kolom yang sama tidak berbeda nyata pada uji BNT dengan taraf $5 \%$.

Tabel 8. Hasil perhitungan Relative Agronomic Effectiveness (RAE) pada bobot buah segar cabai merah keriting dan total biomass.

\begin{tabular}{ccc}
\hline Perlakuan $\left(\mathrm{kg} \mathrm{ha}^{-1}\right)$ & RAE Bobot buah basah (\%) & RAE total biomass (\%) \\
Urea - SP36- KCl - Organonitrofos & & - \\
\hline A $(0-0-0-0)$ & - & 100 \\
B $(300-150-150-0)$ & 28,57 & 20 \\
C $(0-0-0-3000)$ & 42,86 & 540 \\
D $(150-100-100-500)$ & 500 & 620 \\
E $(100-50-50-1000)$ & 200 & 1.240 \\
F $(100-50-50-2000)$ & & \\
\hline
\end{tabular}

Keterangan : Jika nilai RAE $\geq 100 \%$ maka pupuk yang diuji bersifat efektif dibanding perlakuan pupuk standar rekomendasi.

Tabel 9. Index rasio pupuk Organonitrofos dan kombinasinya dengan pupuk kimia.

\begin{tabular}{lccc}
\hline Perlakuan $\left(\mathrm{kg} \mathrm{ha}^{-1}\right)$ & \multicolumn{2}{c}{ Pupuk non - subsidi } & \multirow{2}{*}{ Pupuk subsidi } \\
\cline { 2 - 3 } Urea - SP36 - KCl - Organonitrofos & Eceran & Grosir & \\
\hline A $(0-0-0-0)$ & - & - & - \\
B $(300-150-150-0)$ & 7 & 13,59 & 25 \\
C $(0-0-0-3000)$ & 8 & 8 & 8 \\
D $(150-100-100-500)$ & 14,78 & 14,62 & 20,77 \\
E $(100-50-50-1000)$ & 8,62 & 20,23 & 73,89 \\
F $(100-50-50-2000)$ & 10,59 & 11,91 \\
\hline
\end{tabular}

Keterangan : Jika nilai yang dihasilkan > 1, maka pupuk yang diuji memiliki nilai ekonomis yang baik.

$\mathrm{KCl} \mathrm{ha}^{-1}, 2.000 \mathrm{~kg}$ Organonitrofos ha ${ }^{-1}$ memberikan hasil serapan hara $\mathrm{P}$ dan $\mathrm{K}$ tertinggi.

RAE (Relative Agronomic Effectiveness). Berdasarkan hasil perhitungan RAE (Tabel 8) menunjukkan bahwa penggunaan pupuk Organonitrofos tunggal, pupuk kimia rekomendasi, maupun kombinasinya dengan pupuk kimia dapat dikatakan lebih efektif dibandingkan dengan perlakuan kontrol. Secara agronomis produksi buah cabai yaitu terdapat pada perlakuan E (100 kg urea ha ${ }^{-1}, 50 \mathrm{~kg} \mathrm{SP} 36 \mathrm{ha}^{-1}, 50 \mathrm{~kg}$ $\mathrm{KCl} \mathrm{ha}{ }^{-1}, 1.000 \mathrm{~kg}$ Organonitrofos ha-1) dan F (100 kg urea ha ${ }^{-1}, 50 \mathrm{~kg} \mathrm{SP} 36 \mathrm{ha}^{-1}, 50 \mathrm{~kg} \mathrm{KCl} \mathrm{ha}{ }^{-1}, 2.000 \mathrm{~kg}$ 
Organonitrofos ha ${ }^{-1}$ ) yang memililki nilai lebih besar dari 100\%. Uji Ekonomis Pupuk Organonitrofos. Berdasarkan hasil analisis ekonomis pupuk (Tabel 9), dapat diketahui bahwa semua perlakuan kombinasi pupuk Organonitrofos dengan pupuk kimia bersifat ekonomis, layak secara finansial karena keuntungan yang positif dan nilai efektifitas ekonominya lebih dari satu. Hasil perhitungan menunjukkan perlakuan E (100 $\mathrm{kg}$ urea ha ${ }^{-1}, 50 \mathrm{~kg} \mathrm{SP}-36 \mathrm{ha}^{-1}, 50 \mathrm{~kg} \mathrm{KCl} \mathrm{ha}{ }^{-1}, 1.000 \mathrm{~kg}$ Organonitrofos $\mathrm{ha}^{-1}$ ) yang paling menguntungkan untuk pupuk subsidi maupun non-subsidi untuk usaha tani dalam skala besar.

\section{KESIMPULAN}

Hasil dari penelitian ini dapat disimpulkan bahwa pemberian pupuk Organonitrofos dan kombinasinya dengan pupuk kimia tidak berpengaruh terhadap pertumbuhan, bobot basah dan kering berangkasan, serapan NPK tanaman, dan NPK tanaman + buah cabai merah keriting. Perlakuan E (100 kg urea ha ${ }^{-1}, 50 \mathrm{~kg}$ SP-36 ha-1, $50 \mathrm{~kg} \mathrm{KCl} \mathrm{ha-1,} 1.000 \mathrm{~kg}$ Organonitrofos ha $\left.^{-1}\right)$ dan F (100 kg urea ha ${ }^{-1}, 50 \mathrm{~kg} \mathrm{SP-36} \mathrm{ha-1,50} \mathrm{kg}$ $\mathrm{KCl} \mathrm{ha}{ }^{-1}, 2.000 \mathrm{~kg}$ Organonitrofos ha- ${ }^{-1}$ ) berpengaruh nyata meningkatkan bobot segar, bobot kering buah dan serapan NPK buah cabai merah keriting. Tidak terdapat korelasi antara serapan NPK dengan tinggi tanaman. Terdapat korelasi antara serapan NPK dengan bobot segar, bobot kering buah dan bobot basah berangkasan cabai merah keriting. Perlakuan E efektif dalam meningkatkan produksi buah cabai merah keriting secara agronomis (RAE) dan ekonomis.

\section{DAFTAR PUSTAKA}

BPS. 2012. Luas Panen, Produksi dan Produktivitas Cabai 2009-2011. Artikel. http://bps.go.id. Diakses pada tanggal : 6 November 2012.

Christine, B. 2013. Uji Efektivitas Pupuk Organonitrofos dan Kombinasinya dengan Pupuk Kimia terhadap Pertumbuhan dan Produksi Tanaman Cabai Rawit Kathur (Capsicum frutescens) pada Tanah Ultisol Gedong Meneng. Skripsi. Universitas Lampung. $75 \mathrm{hlm}$.

Goenadi, D.H. 2006. Pupuk dan Teknologi Pemupukan berbasis Hayati dari Cawan Petri ke Lahan Petani. Edisi Pertama. Yayasan John Hi-Tech Idemata. Jakarta. $220 \mathrm{hlm}$.
Elisabeth D. W., M. Santosa dan N. Herlina. 2012. Pengaruh Pemberian Berbagai Komposisi Bahan Organik pada Pertumbuhan dan Hasil Tanaman Bawang Merah (Allium ascalonicum L.). J. Agrotrop. 1(3): 1-12.

Mulyoutami, E., M. van Noordwijk, N. Sakuntaladewi, dan F. Agus. 2010. Perubahan Pola Perladangan: Pergeseran persepsi mengenai para peladang di Indonesia. Bogor, Indonesia. Word Agroforestry Center - ICRAF, SEA Regional Office. $101 \mathrm{hlm}$.

Nugroho, S. G., J. Lumbanraja, Dermiyati, S. Triyono, dan H. Ismono, Y. Triolanda, and E. Ayuandari. 2012. Optimum ratio of fresh manure and grain size of phosphate rock mixture in a formulated compost for Organomineral NP fertilizer. J. Trop. Soils. 17 (2): 121-128.

Nugroho, S.G., Dermiyati, J. Lumbanraja, S. Triyono, H. Ismono, M.K. Ningsih, dan F.Y. Saputri Y.T. 2013. Inoculation effect of $N_{2}$-fixer and $P$ solubilizer into a mixture of fresh manure and phosphate rock formulated as Organonitrofos fertilizer on bacterial and fungal population. J. Trop. Soils. 18 (1): 75-80.

Nursanti. 2008. Pemanfaatan Pupuk Bio-organik terhadap Beberapa Sifat Kimia Ultisol dan Populasi Mikroba Rhizosfer serta Hasil Cabai (Capsicum annuum L.). Jambi. Jurnal Agronomi. 12 (2): 28-33.

Septima,A.R. 2013. Uji Efektifitas Pupuk Organonitrofos dan Kombinasinya dengan Pupuk Kimia terhadap Pertumbuhan, Produksi dan Serapan Hara Tanaman Jagung (Zea mays L.) pada Tanah Ultisol Gedung Meneng. Skripsi. Universitas Lampung. $80 \mathrm{hlm}$.

Setyamidjaya, D. 1986. Pupuk dan Pemupukan. Simplex. Jakarta. $116 \mathrm{hlm}$

Syafruddin, Faesal dan M. Akil. 2007. Pengelolaan Hara pada Tanaman Jagung. Penelitian Tanaman Serealia. Maros, Sulawesi Selatan. balisereal.litbang.deptan.go.id. Diakses pada tanggal : 8 Agustus 2013.

Yusnaini, S, M. A. S. Arif., J. Lumbanraja., S. G. Nugroho, dan M. Nonaka. 2004. Pengaruh Jangka Panjang Pemberian Pupuk Organik dan Inorganik serta Kombinasinya terhadap Perbaikan Kualitas Tanah Masam Taman Bogo, J. Tanah Trop. 18: 155-162. 